\title{
A New Fish Record in the Yangtze Estuary: Slender Mandarinfish Siniperca roulei
}

\author{
ZHANG Heng ${ }^{1}$, FAN Wei ${ }^{1, *}$, ZHANG Jian ${ }^{2}$ \\ (1.Key Laboratory of Fisheries Resources Remote Sensing and Information Technology Resources, East China Sea Fisheries Research \\ Institute, Chinese Academy of Fishery Sciences, Shanghai 200090, China; 2.The Key Laboratory of Shanghai Education Commission for \\ Oceanic Fisheries Resources Exploitation, College of Marine Sciences, Shanghai Ocean University, Shanghai 201306, China)
}

\begin{abstract}
A new recorded fish (Siniperca roulei) of the Yangtze estuary and Shanghai district was collected at the west end of Chongming Island in the survey on the intertidal fishes in May, 2008. It belongs to Family Serranidae of Order Perciformes. Its main features were described as the following: body slim and long, nearly tubby; head long and a little flat, and proboscis sharp; oral fissure big, the mandible apparent protruding, and the upper jaw outstretch to the area under the eye; ten thin sawteeth and two declining spurs at the rear edge and the ventrolateral edge of the front operculum, respectively; one flat spine at the back-end of the operculum with one short spine at its up-end; body tawny and some anomalistic macula and dark spots on the head and both sides of the body. Owing to the overfishing and water pollution, the resource amount of the fish has decreased sharply in recent decades. It has been listed in China Red Book of Endangered Animals. Currently, very few studies on this fish species have been carried out, especially those on their breeding, feeding and growing characteristics are even scare. Hence, it is extremely urgent to carry out the study and conservation on this species.
\end{abstract}

Key words: Yangtze estuary; New recorded species; Slender mandarinfish

\author{
长江河口及上海地区鱼类新记录种一一长身鳜 \\ 张 衡 ${ }^{1}$, 㚞 伟 ${ }^{1,}{ }^{*}$, 张 健 $^{2}$ \\ (1.中国水产科学研究院东海水产研究所 渔业资源遥感信息技术重点开放实验室, 上海 200090; 2. 上海海洋大学海洋科学学院 \\ 大洋生物资源开发和利用上海高校重点实验室, 上海 201306)
}

摘要: 2008 年 5 月在崇明岛西端潮间带水域进行鱼类调查时, 发现一尾长江河口及上海地区的鱼类新记录种 ——长身鲠, 隶属鲇形目鮨科。主要特征如下: 体较细长, 近似圆筒形; 头长, 稍平扁。吻尖。口裂大, 下领明 显突出; 上领达眼下方。前鳃盖骨后缘有 10 枚细锯齿, 腹缘有向前倾斜的鰓盖骨棘 2 枚。鰓盖后端有 1 枚扁平棘, 其上端有较小的短棘 1 枚。体黄褐色, 头背和体侧具不规则的黑点和黑斑。近数十年来由于过度捕捞和水环境污 染等原因, 导致其资源量急剧减少, 已被我国列入濒危动物红皮书。目前, 关于长身䰻的资源状况研究十分薄弱, 尤其是其繁殖习性、食性和发育等生物学特征研究还未见报道。因此, 亟待开展此方面的研究和保护工作。

关键词: 长江河口; 新记录种; 长身䰻

中图分类号：Q959.483 文献标识码：A 文章编号：0254-5953-(2009)01-0109-04

Slender mandarinfish (Siniperca roulei) is a special local freshwater fish in east China, belonging to Family Serranidae of Order Perciformes. Its local name is bamboo-tube-like or colorful mandarinfish. Once it was widely existed in the south area to the Yangtze River, such as Zhejiang, Fujian, Jiangxi, Hunan and Guizhou Provinces, but its population was limited to a few numbers (Cheng \& Zheng, 1987; Ni \& Wu, 2006).

Received date: 2008-08-27; Accepted date: 2008-10-22

Foundation items: National Key Technology R\&D Program (2006BAD09A05); Opening Project of The Key Laboratory of Shanghai Education Commission for Oceanic Fishery Resources Exploitation (KF200802)

"Corresponding author (通讯作者), E-mail: dhyqzh@sh163.net

收稿日期: 2008-08-27; 接受日期: 2008-10-22

基金项目：国家科技支撑计划（2006BAD09A05）; 大洋生物资源开发和利用上海市高校重点实验室开放基金(KF200802)

第一作者简介: 张衡 (1979-), 男, 博士, 主要从事鱼类生态学和渔业遥感研究。E-mail: zheng615@sina.com.cn 
Owing to the overfishing and water pollution, the resource amount of the fish has decreased sharply in recent decades. It has been listed in China Red Book of Endangered Animals (Endangered level: NT, near threatened status) in 1998 (Le \& Chen, 1998)。

A slender mandarinfish was collected in the intertidal flat at the west end of Chongming Island $\left(31^{\circ} 48.8^{\prime} \mathrm{N}, 121^{\circ} 10.9^{\prime} \mathrm{E}\right)$ in the Yangtze estuary on May 8th, 2008. After identifying and reading the related scientific literature, it was proved that the collected fish is a newly recorded species in Yangtze estuary and Shanghai city (Chen et al, 1976; Zeng et al, 1990; Zhuang et al, 2006; Ni \& Wu, 2006; Zhang \& Lu, 2007). The method of morphologic measuring of the sample refers to $\mathrm{Ni}$ et al (1990).

\section{Morphology characteristics of the sample}

Body length: $96.8 \mathrm{~mm}$; total length: $108.1 \mathrm{~mm}$; body weight: $14.02 \mathrm{~g}$. Dorsal fin XIII, 10; Anal fin III, 7; Ventral fin I, 5; Pectoral fin 14. The line of sensory intacts (Fig. 1; Tab. 1). The only one specimen is kept in the Key Laboratory of Fisheries Resources Remote Sensing and Information Technology Resources, East China Sea Fisheries Research Institute.

Body thin and elongate, nearly tubby, greatly different from other Siniperca species (Tab. 2). Head elongate and slightly compressed. The eyes medium size and close to the edge of the head back. The oral fissure big and a bit declining, while the mandible apparent protruding and upper jaw outstretch to the area under the eye. Some pointed teeth in jaws, vomer and palatine bones. When closing the mouth, the frontend canine teeth of mandible stick out. The tongue thin and dissociative, while its gill opening big. Ten thin sawteeth and two declining spurs at the rear edge and ventrolateral edge of front operculum, respectively. One flat spine is at the back-end of the operculum with one short spine at its up-end. Gill arch degenerates to vestigial granular. Anus closes to anal fin. Small feeble ctenoid scales cover most parts of the body except the head and front belly. Front-end of lateral line is higher than its position in the middle, while reaches the medium height at the tail. Dorsal fin continuous and its starting point on the base of pectoral fins, while an indentation between the base of fin spines and fin rays. The start-point of anal fin under the last fin spine of dorsal fin. Pectoral fin circular and the back-end of it not exceed the back-end of the ventral fin. Two ventral fins close to its chest and circular like tail fins. Body is tawny and some anomalistic macula and dark spots on the head and both sides of the body. Also some point burrs occur on the dorsal fins, tail fins, anal fins and ventral fins. Its belly grey and all fins yellow.
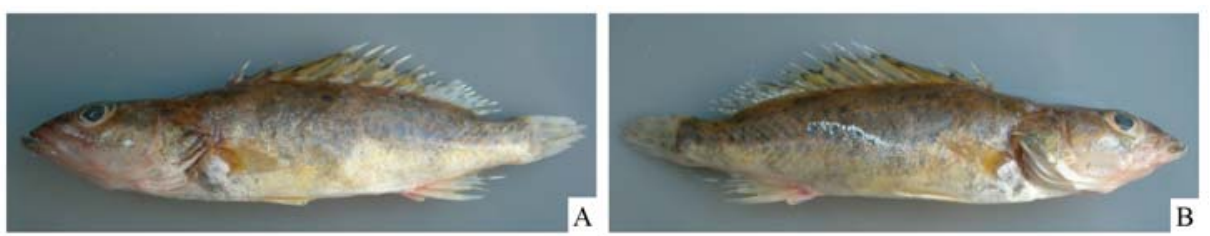

Fig. 1 Lateral view of Slender Mandarinfish (A. left side of view; B. right side of view)

Tab. 1 Morphology data of Siniperca roulei

(mm)

\begin{tabular}{lclc}
\hline \multicolumn{1}{c}{ Items } & \multicolumn{1}{c}{ Items } & 49.8 \\
\hline Total length & 108.1 & Length of base of the dorsal fin & 13.0 \\
Body length & 96.8 & Length of base of the anal fin & 19.8 \\
Head length & 36.6 & Body height of pelvic fin origin & 14.5 \\
Snout length & 10.1 & Maximum body width & 11.1 \\
Postorbital length & 15.9 & Caudal peduncle length & 8.2 \\
Maximum head width & 12.4 & Caudal peduncle height & 4.9 \\
Interorbital width & 3.8 & Body length/body height & 2.6 \\
Eye diameter & 8.1 & Body length/head length & 3.6 \\
Lower jaw length & 15.5 & Head length/snout length & 1.4 \\
Predorsal length & 33.2 & Caudal peduncle length/Caudal peduncle height & 4 \\
Length of snout to origin of the anal fin & 70.2 & Number of nostrils & 93 \\
Length of snout to anus & 66.5 & Number of sensory line scales & \\
\hline
\end{tabular}


Tab. 2 Comparison of morphological characters between Siniperca roulei and other Siniperca species (Data of other species are cited from the following literatures: Chen et al, 1976; Ni et al, 1990; Ni \& Wu, 2006)

\begin{tabular}{|c|c|c|c|c|c|}
\hline Species & Body types & Features of head & $\begin{array}{l}\text { Body length/ } \\
\text { body height }\end{array}$ & $\begin{array}{l}\text { Scales in } \\
\text { lateral line }\end{array}$ & Spots or stripes \\
\hline Siniperca roulei & $\begin{array}{l}\text { Body thin and long, } \\
\text { nearly tubby }\end{array}$ & $\begin{array}{l}\text { Sharp mouth, lower } \\
\text { jaw protruding }\end{array}$ & $4.7-5.5$ & $89-99$ & $\begin{array}{c}\text { Anomalistic macula and dark spots } \\
\text { on the head and body sides }\end{array}$ \\
\hline S. chuatsi & $\begin{array}{l}\text { High body, side flat, } \\
\text { ridgy backside }\end{array}$ & $\begin{array}{l}\text { Big mouth, upper jaw } \\
\text { extend trailing edge of } \\
\text { eye }\end{array}$ & $2.7-3.1$ & $121-128$ & $\begin{array}{l}\text { Anomalistic macula and dark spots } \\
\text { on the sides; } 4-5 \text { dark horizontal } \\
\text { stripes near the base of dorsal } \\
\text { fin }\end{array}$ \\
\hline S. kneri & $\begin{array}{l}\text { High body, side flat, } \\
\text { ridgy backside }\end{array}$ & $\begin{array}{l}\text { Eye bigger, lower jaw } \\
\text { protruding, upper jaw } \\
\text { outstretch to the area } \\
\text { under the eye }\end{array}$ & $2.8-2.9$ & $98-105$ & $\begin{array}{l}\text { Anomalistic macula and dark spots } \\
\text { on the sides; } 5-6 \text { unconspicuous } \\
\text { horizontal stripes on the sides }\end{array}$ \\
\hline S. scherzeri & $\begin{array}{l}\text { Body long; circular } \\
\text { backside, not very } \\
\text { ridgy }\end{array}$ & $\begin{array}{l}\text { Big mouth, lower jaw } \\
\text { protruding }\end{array}$ & $3.4-4.0$ & $104-124$ & $\begin{array}{l}\text { Rounded dark spots on the head, } \\
\text { operculum and body sides }\end{array}$ \\
\hline S. undalata & $\begin{array}{l}\text { High body, side flat, } \\
\text { ridgy backside }\end{array}$ & $\begin{array}{l}\text { Upper and lower jaw } \\
\text { equilong }\end{array}$ & 3.6 & 92 & Some wavy stripes on the sides \\
\hline S. loona & $\begin{array}{l}\text { Side flat, slight } \\
\text { ridgy backside }\end{array}$ & $\begin{array}{l}\text { Upper and lower jaw } \\
\text { almost equilong }\end{array}$ & $3.0-3.9$ & $64-70$ & $\begin{array}{l}\text { Anomalistic macula and dark spots } \\
\text { on the sides }\end{array}$ \\
\hline
\end{tabular}

\section{Distribution and current resource status}

Most investigations have proved that the slender mandarinfish once mainly distributed in the water areas of Dongting Lake, Poyang Lake and some tributaries in the middle reach of Yangtze River (Chen et al, 1976), and only occasionally be found in Chaohu Lake, Gucheng Lake and Yangcheng Lake in the lower reach of Yangtze River (Zeng et al, 1990; Ni \& Wu, 2006), but never be found in the Yangtze estuary and Shanghai district (Fig. 2). It is a mountain creek and lake fish which prefers to live in the water area with pebble bottom and clean running water. It is a carnivorous fish which mainly feeds on small fishes, shrimps and aquatic insects. In the Yangtze estuary, this kind of fish has never been found before. The reasons may lie on the fact that the estuary has brackish water and muddy sand bottom (Ni et al, 1990).

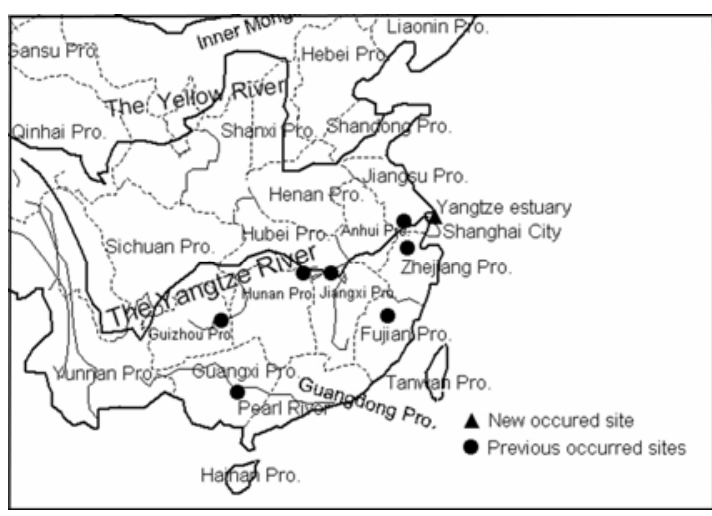

Fig. 2 Distribution sites of Siniperca roulei in China
This sampling site lies in the west of Yangtze estuary where the water salinity can reach close to 0 in drought seasons (April to October) every year. More than 120 samples were sampled with the tide-stow-net (about $1000 \mathrm{~m}$ length, $1 \mathrm{~m}$ height with $1 \mathrm{~mm}$ mesh size) in the intertidal zone from May 2005 to July 2008. As a result, only one slender mandarinfish has been collected. It also suggested that this fish is very rare in the Yangtze estuary. After reviewing the most related literatures (Chen et al, 1976; Ni et al, 1990; Ni \& Wu, 2006) and interviewing local fishermen, the fish was proved to be not a cultivated species. Because its population is very small, it suggested that the fish could not be introduced into Yangtze estuary by mankind. Hence, whether its appearance in the fresh water of the estuary can prove that this area would also be a good place for their surviving? Or whether with the increasing run off in the Yangtze River during the spring, its movement extent expands from lakes in the lower reach of Yangtze River to the estuary? Or maybe there are a number of this fish live in the Yangtze estuary? All these problems need further research.

Now, only two species of Serranidae family fishes have been frequently found in the Yangtze estuary and Shanghai district, i.e. Siniperca chuatsi and S. scherzeri. The former has great populations and frequently occurs in the estuary and inland rivers or lakes, but the latter only has a few populations and occurs in inland rivers or lakes (such as Dianshan lake) (Ni et al, 1990). Many studies have report the population, distribution and 
biology features of these two species of Serranidae family fishes, but there are very few studies on the resources status of $S$. roulei, especially studies on the characteristics of breeding, feeding and growing of this species. Currently, some evidences have proved that the population of slender mandarinfish has decreased sharply. It has grown to be a near threatened fish owing to the overfishing and water pollution. It is extremely urgent to

\section{References:}

Chen PX, Yi BL, Deng ZL. 1976. Fishes in Yangtze River [M]. Beijing: Science Press.

Cheng QT, Zheng BS. 1987. Systematic Synopsis of Chinese Fishes [M] Beijing: Science Press.

Le PQ, Chen YY. 1998. Fish (series of China Red Book of Endangered Animals edit by WANG Song) [M]. Beijing: Science Press.

Ni Y, Wang YH, Xu CY, Xiong GQ. 1990. The fishes of Shanghai area[M]. Shanghai: Science and Technology Press in Shanghai.

Ni Y, Wu HL. 2006. Fishes of Jiangsu Province [M]. Beijing: China carry out researches and conservation on the fish resource, such as technology of its artificial fecundation.

Acknowledgements: Thanks go to the fisherman LIU Ben-zhu for assisting to collect the samples! Specially thank Dr. TONG Chun-fu for revised the manuscript!

Agriculture Press.

Zeng XC, Zhao NG, Liu LH, Leng YZ, Wu GX. 1990. Fish resources of the Yangtze River [M]. Beijing: Marine Press.

Zhang H, Lu JJ. 2007. An application on the calculation of taxonomic diversity of fish in the Yangtze River Estuary [J]. J East China Normal University (Natural Science), 2: 11-22.

Zhuang P, Wang YH, Li SF, Deng SM, Li CS, Ni Y. 2006. Fishes of the Yangtze estuary $[\mathrm{M}]$. Shanghai: Science and Technology Press in Shanghai.

\section{昆明动物研究所动物模型与人类疾病机理重点实验室 被正式批准成为中国科学院重点实验室}

昆明动物研究所动物模型与人类疾病机理重点实验室成立于 2005 年 12 月 20 日, 符合中 国科学院中长期发展规划和知识创新工程的总体部署，是我所三大中长期发展领域之一。该 实验室主要针对艾滋病、抑郁症和毒品成瘾等疾病建设和完善疾病灵长类动物模型, 研究疾 病发生的细胞分子机理和调控靶点, 并致力于具有自主知识产权的新药、疫苗和新技术研发。 在实验室全体成员的共同努力下，历经 3 年的建设和发展，在抗艾滋病和抗抑郁症新药药效 学评价关键技术、疾病灵长类动物模型、生物毒素结构与功能、疾病遗传学等研究方面取得 了显著成果，部分成果已达到国内外先进水平。2009年9月，经向中国科学院提出申请，通 过院计划财务局组织的专家组的严格现场评审，该实验室于 2008 年 12 月 19 日被正式批准为 中国科学院动物模型与人类疾病机理重点实验室。 